\title{
ROLE OF NGOs, CBOs AND PRIVATE ORGANIZATIONS FOR EFFICIENT MANGEMENT OF MUNICIPAL SOLID WASTE IN KATHMANDU VALLEY \\ Ram Chandra Bhattarai*
}

\begin{abstract}
This paper attempts to discuss the role of Community based, nongovernmental and private institutions for the management of municipal solid waste in Kathmandu Valley. It is based on secondary information available from different sources. Studies reveal that private institutions, Community Based Organizations (CBOs) and Non Governmental Organizations are collecting about $60 \%$ of the total waste generated within Kathmandu Valley from door-to-door of the generators. These institutions are also contributing to reduce about $40 \%$ of the municipal cost for the collection of waste. Study reveals that household segregation and compositing is considered as the best option for the efficient management of municipal solid waste in the cities of developing countries like Kathmandu. This is possible only through the involvement of CBOs, NGOs and private sector.
\end{abstract}

\section{INTRODUCTION}

The emergence of the philosophy of solid waste management as reduce, reuse, recycle and recover is providing support for community groups and Non-governmental Organizations (NGOs) in the cities of developing countries and encouraging separation and recycling at the source. Given the social goals of many projects and the community characteristics, communitybased projects in developing the cities of country cities may require more complex planning and co-ordination than reduction and recycling schemes as practiced in developed country cities (Furedy1996).

Studies show that community participation is essential for the sustainable management of waste in developing countries. In many developing country cities there is a problem of waste collection and proper disposal. Studies show that in Nairobi city waste is not collected for 60 percent of time and 91 percent of the respondents were not provided with Nairobi city council waste storage receptacles. Lack of skilled and technical human resources, poor management and financing of resources, and laxity among employees are viewed as the major contributing factors for the poor management of solid waste in Nairobi (Mwanthi et al, 1997). The involvement of people through NGOs and CBOs has helped to reduce the cost of solid waste management in many developing country cities (Reddy et al, 1998).

This paper attempts to discuss the role of CBOs, NGOs and private institutions for the management of municipal solid waste in Kathmandu valley. It is merely based on secondary information available. It attempts to discuss the

*Associate Professor, Patan Multiple Campus, Patandhoka, Tribhuvan University, Lalitpur, Nepal 
experience of some of the developing country cities for the management of solid waste with the involvement of CBOs, NGOs and private institutions. Finally it attempts to discuss the role of NGOs, CBOs and private organizations within the five municipalities of Kathmandu Valley.

\section{EXPERIENCES OF CITIES IN DEVELOPING COUNTRIES}

NGOs and CBOs have emerged as successful institutions for the management of solid waste in many developing countries. One such example is found in the Muskan Joyti Samitit (MJS) in Lucknow, India (Lal 2000). MJS started its work in a small town with a few workers and convinced the residents about the benefits of garbage removing regularly. Initially the residents considered garbage removal as the municipality's responsibility and refused to participate in the NGO-led program. It gained success in another locality. Under the MJS scheme, solid waste collection is free for the first two months. Monthly charges are levied only from the third month after residents have benefited from the door-to-door collection of garbage as well as improvement in the cleanliness of their surroundings. About 80 percent of the residents pay the monthly collection charge after the first two months of free service (Lal 2000).

The study shows that municipal waste collection services are more effective when they work in partnership with community-led primary collection from households. Urban communities, especially those, who rent their properties, are more reactive than proactive. The demand for improved solid waste management needs to be facilitated by individuals or groups. Where a reliable service can be guaranteed the community members are willing to pay for it. Community participation is indispensable to the success of solid waste management at the local level (Ahsan et al. 2000).

In Calcutta, the Municipal Corporation has introduced a garbage carrying and removal charge of Rs. 20 per occurrence event in domestic areas and Rs. 50 (minimum) in commercial areas to any person or premises dropping garbage in the street. House-to-house collection of garbage provides cleaning and removal services to over nine million of Calcutta's day-time population. Over 40 percent of secondary garbage collection is now through private carriers who are paid on per tonnage basis of waste handled (DFID 1999).

The domestic solid waste management program in the low-income area of Harkesh Nagar in Delhi demonstrates that decentralization of solid waste management efforts enforces upward social mobility of rag pickers. ACCORD, a national NGO with collaboration from the local bodies, has organized rag pickers for doorstep collection service and youth groups. It covers about 50,000 population of this area (DFID 1999).

Community-based approaches to solid waste management are supported by SKAA through self-financing at the household level. SKAA, as an intermediary, organizes and enables local communities to manage primary collection and facilities linkages with the municipal corporation. The municipal corporation organizes secondary collection and disposal to landfill (Qureshi 2000).

Ahamdabad Municipal Corporation provides a list of residential areas and initiates public awareness campaigns, the corporate sector mobilises funds for 
bags to collect dry recyclable garbage, and SEWA has organized paper pickers known as Arogya Bhaginis for the collection of dry recyclable garbage. Out of estimated 30,000 rag pickers in Ahmedabad, 6,000 are members of SEWA (UNDP-World Bank 1999).

The city of Chennai generates on average 3,000 metric tons of garbage every day; of this, the local Municipal Corporation collects 2,000 metric tons. At present, Exnora is responsible for 600 metric tons of the primary collection of the garbage in Chemical city alone, complementing the efforts of the municipal authorities by reducing the number of garbage collection points. In total about 1,500 neighborhood groups are functioning today in the city of Chennai. Street beautifiers, paid through household collection funds, are organized by civic Exnoras to undertake collection of garbage. The garbage is taken to common collection points where the corporation vehicles take the solid waste for landfill and recycling. Biodegradable garbage is processed through vermi culture, and used as compost or natural manure. The non-biodegradable garbage is segregated and sold by the street beautifiers (Nirmal 2000).

In Kuppam (Andhra), women in most cases are willing to form user's groups and pay between Rs. 2-30 a month for improved services. Door-to-door collection is possible only through this community participation (Sisodia 2000).

Small-scale compost plants located within the community could be effective in reducing the volume and quantity of waste to landfill, provided appropriate scientific composting method is followed (Enayetullah 2000). Decentralized compost plant is commercially viable as can be seen from the Mirpur (Bangladesh) experience. It is also found that women from informal sector are interested to work in composting plants and it is socially acceptable (Enayetullah 2000).

Despite private provision initiatives, relevant public agencies should not neglect the development of adequate and properly maintained waste disposal sites. The small-scale solid waste service operators may neither be able nor willing to acquire and develop such sites (Ogu 2000).

In Mexicali, there is a great potential for recycling and for reducing waste volumes in a neighborhood. Most of the waste was recyclable and a recycling program would bring benefits not only by reducing waste volumes and pollution but also by greatly lengthening the life of the existing city dump (OjedaBenite et al. 2000).

\section{CBOs, NGOs AND PRIVATE ORGANIZATIONS WORKING WITHIN KATHMANDU VALLEY AND THEIR ROLE}

There is a not proper record regarding the number of CBOs and NGOs providing solid waste management services in Kathmandu Valley (JICA, 2005). However, as per the record of affiliation about 40 private organizations including NGOs and CBOs are working within these municipalities. The summary of those institutions is presented in table 3, 4, 5, 6 and 7 respectively. According to the Household Behavior and Attitude Survey on SWM conducted by the JICA Study Team, out of the 162 households surveyed in LSMC, over 73\% of the respondent sample HHs identified NGOs and CBOs as major service providers. Major NGOs such as Nepal Pollution Control and Environment Managing Center (NEPCEMAC), 
Women Environmental Preservation Committee (WEPCO), and National Environmental Pollution Control Nepal (NEPCO) have been reported to provide service for 2,850 HHs, 1,100 HHs, and $800 \mathrm{HHs}$ respectively for a collection fee of about Rs. 20 to 75 per household. This signifies that services provided by the private sector is prevalent in Lalitpur, nevertheless, the municipality has little information or management control over these activities (JICA 2005).

Table 1. NGOs, CBOs and Private Organizations Working within Kathmandu Metropolitan City

\begin{tabular}{|c|c|c|c|c|c|c|c|}
\hline No & $\begin{array}{c}\text { Organization } \\
\text { Name }\end{array}$ & $\begin{array}{c}\text { Organi- } \\
\text { zational } \\
\text { Status }\end{array}$ & $\begin{array}{l}\text { Ward } \\
\text { No. }\end{array}$ & $\begin{array}{l}\text { Member - } \\
\text { ship } \\
\text { (approx.) }\end{array}$ & $\begin{array}{l}\text { Collection } \\
\text { frequency }\end{array}$ & $\begin{array}{c}\text { Street } \\
\text { Sweeping }\end{array}$ & $\begin{array}{l}\text { No. of } \\
\text { Staff }\end{array}$ \\
\hline 1. & $\begin{array}{l}\text { Kathmandu } \\
\text { Mahanagar Solid } \\
\text { Waste } \\
\text { Management } \\
\text { Services }\end{array}$ & $\begin{array}{l}\text { Private } \\
\text { Company }\end{array}$ & 1 & 1,000 & Daily & 18 km (pitched) & 57 \\
\hline 2. & $\begin{array}{l}\text { SILT } \\
\text { Environmental } \\
\text { Services-Nepal }\end{array}$ & $\begin{array}{l}\text { Private } \\
\text { Company }\end{array}$ & $\begin{array}{c}13,14 \\
15\end{array}$ & 3,900 & Alternately & 9 km (pitched) & 79 \\
\hline 3. & $\begin{array}{l}\text { A to Z Cleaning } \\
\text { Services }\end{array}$ & $\begin{array}{l}\text { Private } \\
\text { Company }\end{array}$ & $\begin{array}{l}24,22, \\
25\end{array}$ & 1,100 & Daily & $\begin{array}{l}\text { New Road } \\
\text { Salik to Gate; } \\
\text { Ganesh Chowk, } \\
\text { Indra Chowk }\end{array}$ & 48 \\
\hline 4. & $\begin{array}{l}\text { KP Cleaning } \\
\text { Services }\end{array}$ & $\begin{array}{l}\text { Private } \\
\text { Company }\end{array}$ & 2 & 400 & NA & $\begin{array}{l}3 \mathrm{~km} \text { (pitched), } \\
1 \mathrm{~km} \text { (not } \\
\text { pitched) }\end{array}$ & 26 \\
\hline 5. & $\begin{array}{l}\text { B and B } \\
\text { Cleaning } \\
\text { Services }\end{array}$ & $\begin{array}{l}\text { Private } \\
\text { Company }\end{array}$ & $\begin{array}{c}8,9 \\
31,32, \\
34\end{array}$ & 500 & Daily & $\begin{array}{l}10.5 \text { km } \\
\text { (pitched), } 1.5 \\
\text { km (not } \\
\text { pitched) }\end{array}$ & 35 \\
\hline 6. & $\begin{array}{l}\text { Women } \\
\text { Environment } \\
\text { Avian }\end{array}$ & NGO & 34 & $500-600$ & Daily & $\begin{array}{l}\text { Sankhamul } \\
\text { pool to Niketan }\end{array}$ & 11 \\
\hline 7. & $\begin{array}{l}\text { Jana Jagarukh } \\
\text { Safa Suggar } \\
\text { Campaign }\end{array}$ & NGO & 10,34 & 5,000 & NA & 30 km (pitched) & 53 \\
\hline 8. & $\begin{array}{l}\text { Sarsafai Avian } \\
\text { Pvt. Ltd. }\end{array}$ & NGO & $3,5,7$ & 1,300 & Alternately & & 20 \\
\hline 9. & Bouddha Youth & $\mathrm{CBO}$ & 6 & 1,500 & Alternately & 20 km (pitched) & 32 \\
\hline 10. & $\begin{array}{l}\text { Nepal Pollution } \\
\text { Control and } \\
\text { Environment } \\
\text { Center } \\
\text { (NEPCEMAC) }\end{array}$ & NGO & $\begin{array}{c}3,4,5, \\
16\end{array}$ & 5,600 & Daily & $\begin{array}{l}17 \text { km (mostly } \\
\text { not pitched) }\end{array}$ & 84 \\
\hline 11. & $\begin{array}{l}\text { Samyukta Sewa } \\
\text { Pvt. Ltd. }\end{array}$ & $\begin{array}{l}\text { Private } \\
\text { Company }\end{array}$ & 6,7 & 1,200 & Daily & 5 to $6 \mathrm{~km}$ & 16 \\
\hline 12. & $\begin{array}{l}\text { Nepal Fulbari } \\
\text { Pollution Control } \\
\text { Centre }\end{array}$ & NGO & 3,4 & 600 & Alternately & $\begin{array}{l}\text { Gongabu } \\
\text { chowk to } \\
\text { Thamel (not } \\
\text { main road) }\end{array}$ & 20 \\
\hline 13. & $\begin{array}{l}\text { Environment } \\
\text { Conservation } \\
\text { Initiative-Nepal }\end{array}$ & $\begin{array}{l}\text { Private } \\
\text { Company }\end{array}$ & $\begin{array}{c}7,9 \\
16,29, \\
33\end{array}$ & 3,000 & Daily & $\begin{array}{l}\text { Within Ring } \\
\text { Road (not main } \\
\text { road) }\end{array}$ & 36 \\
\hline 14 & $\begin{array}{l}\text { Hamro Sarsafai } \\
\text { Avian Pvt. Ltd. }\end{array}$ & $\begin{array}{l}\text { Private } \\
\text { Company }\end{array}$ & 35 & $\begin{array}{l}1,300- \\
1,400\end{array}$ & Alternately & No sweeping & 31 \\
\hline 15. & $\begin{array}{l}\text { Karmachari } \\
\text { Kalayan Kkosh }\end{array}$ & NA & NA & NA & NA & NA & NA \\
\hline
\end{tabular}

Source: JICA 2005. 
Table 1 shows that there are about 15 private institutions (including CBOs and NGOs) working within Kathmandu Metropolitan City ${ }^{1}$. About $60 \%$ of the total waste collection is collected by these CBOs, NGOs and private institutions. These institutions are providing direct employment to nearly 500 people. They are also performing the job of street sweeping within their working area.

Table 2. Major NGOs and BCOs working for SWMS in Lalitpur

\begin{tabular}{|c|c|c|c|}
\hline Name of NGOs/CBOs & $\begin{array}{c}\text { Year of } \\
\text { foundation }\end{array}$ & $\begin{array}{c}\text { Number of } \\
\text { staff }\end{array}$ & Working Areas \\
\hline $\begin{array}{l}\text { Women Environmental } \\
\text { Prevention Committee } \\
(\mathrm{WEPCO})^{*}\end{array}$ & 1996 & $\begin{array}{l}28 \text { paid staff } 7 \\
\text { volunteers }\end{array}$ & $\begin{array}{l}\text { Door-to-door collection, Recycling of } \\
\text { paper, Awareness camping, Sweeping, } \\
\text { Composting, Training in Wards } 1 \text { and } \\
10\end{array}$ \\
\hline $\begin{array}{l}\text { Women Environmental } \\
\text { Group } \\
\text { (WEG)* }\end{array}$ & 1997 & $\begin{array}{l}12 \text { paid staff } 6 \\
\text { volunteers }\end{array}$ & $\begin{array}{l}\text { Door-to-door collection in Wards 3, } \\
10 \text { and } 22 \text { (600 HHs), Awareness } \\
\text { campaign, Compositing in Ward 10, } \\
\text { Recycling in Ward } 10\end{array}$ \\
\hline $\begin{array}{l}\text { Nepal Pollution Control } \\
\text { Environmental } \\
\text { Management* }\end{array}$ & 2001 & 137 & $\begin{array}{l}\text { Door-to-door collection in Wards } 2,3 \text {, } \\
4,5,13,14 \text { and } 19(2,500-2,800 \mathrm{HHs}) \\
\text { and pilot project with support of LSMC } \\
\text { in Wards } 4,5 \text {, and } 13(150 \mathrm{HHs})\end{array}$ \\
\hline $\begin{array}{l}\text { Society for Urban Poor } \\
\text { (SOUP) }\end{array}$ & 1992 & $\begin{array}{l}2 \text { paid and } 33 \\
\text { volunteers }\end{array}$ & $\begin{array}{l}\text { Community development including } \\
\text { clan up in Wards } 7 \& 17 \text { and } 18 \text { \& } \\
22 \text {, Compositing ( } 560 \mathrm{HHs} \text { ) }\end{array}$ \\
\hline $\begin{array}{l}\text { Environmental Camps for } \\
\text { Conservation Awareness } \\
\text { (ECCA) }\end{array}$ & 1987 & $\begin{array}{l}8 \text { paid and } 50 \\
\text { volunteers }\end{array}$ & $\begin{array}{l}\text { Public awareness on environmental } \\
\text { education }\end{array}$ \\
\hline Zero Waste Nepal & 2001 & 20 Volunteers & $\begin{array}{l}\text { Public awareness and campaign on } \\
\text { SWM }\end{array}$ \\
\hline $\begin{array}{l}\text { Women's Initiative for } \\
\text { Environmental and } \\
\text { Development (WEID) }\end{array}$ & 2000 & $\begin{array}{l}3 \text { paid and } 25 \\
\text { volunteers }\end{array}$ & $\begin{array}{l}\text { Door-to-door collection in Ward } 2 \\
\text { ( } 300 \text { HHs }+2 \text { schools) }\end{array}$ \\
\hline Kathmandu 2020 & 1995 & $\begin{array}{l}1 \text { paid and } \\
1,500 \\
\text { volunteers }\end{array}$ & $\begin{array}{l}\text { Compositing (20 HHs), Awareness } \\
\text { campaign }\end{array}$ \\
\hline
\end{tabular}

Source: JICA Study Team, 2004, "Interview and Questionnaire Survey on Household, Establishment and NGOs/CBOs regarding Solid Waste Management in the Kathmandu Valley".

Note:* According to LSMC, there is co-ordination with LSMC at program/activity levels.

Table 2 shows that about 9 institutions are working within Lalitpur submetropolitan city. About 2000 people including volunteers are engaged for the managing solid waste within Lalitpur sub-metropolitan city. They manage the waste by collecting from door-to-door, sorting the collected waste and compositing. They also perform street sweeping within their working area. More than $60 \%$ of the door to door collection is made by these private institutions within Lalitpur sub metropolitan city (JICA 2005).

1 The number of institutions working within the Metropolitan City may be many since many institutions work without registration. 
Table 3. Major NGOs/CBOs Working in the Field of SWM in BKM

\begin{tabular}{|l|c|l|l|}
\hline Name of NGOs/CBOs & $\begin{array}{c}\text { Year of } \\
\text { foundation }\end{array}$ & Number of Staff & \multicolumn{1}{|c|}{ Working Areas } \\
\hline Prayanta-Nepal & 2000 & 18 volunteers & $\begin{array}{l}\text { Recycling training/ education } \\
\text { for children, teachers }\end{array}$ \\
\hline Kathmandu 2020 & 1995 & $\begin{array}{l}\text { 1 paid and 1,500 } \\
\text { volunteers }\end{array}$ & 3 R program for SWM \\
\hline
\end{tabular}

Source: JICA Study Team, 2004 "Interview and Questionnaire Survey on Households, Establishment and NGOs/CBOs regarding Solid Waste Management in the Kathmandu Valley".

Table 3 shows the summary of these institutions working within Bhaktapur municipality. There are only two private institutions working in Bhaktapur District. These institutions are mainly working for recycling training and education activities. Bhaktapur Municipality has relatively small area and hence only two NGOs or CBOs are working for the management of municipal solid waste.

Table 4. Major NGOs/CBOs Working in the Field of SWM in MTM

\begin{tabular}{|c|c|c|c|}
\hline Name of NGOs/CBOS & $\begin{array}{c}\text { Year of } \\
\text { foundation }\end{array}$ & $\begin{array}{c}\text { Number } \\
\text { of Staff }\end{array}$ & Working Areas \\
\hline $\begin{array}{l}\text { Samyukta Mahila } \\
\text { Uthan Samittee* }\end{array}$ & 1993 & $\begin{array}{c}\text { 30-35 } \\
\text { Volunteers }\end{array}$ & $\begin{array}{l}\text { Awareness, compositing (210 HHs), } \\
\text { Bucket distribution (120 HHs) with } \\
\text { support of World Vision, Cleanup } \\
\text { program in Ward } 1\end{array}$ \\
\hline Innovative Idea & 2000 & 10 & $\begin{array}{l}\text { Paper recycling in collaboration } \\
\text { with ECCA }\end{array}$ \\
\hline JESIS & NA & NA & $\begin{array}{l}\text { Bucket distribution in Ward } 7 \text { (135 } \\
\text { HHs) }\end{array}$ \\
\hline World Vision & 2000 & 150 & $\begin{array}{l}\text { Bucket distribution through } \\
\text { Samyukta Mahila Uthan Samittee in } \\
\text { Ward } 1 \text { ( } 120 \mathrm{HHs}) \text {, Community- } \\
\text { based sanitation activities including } \\
\text { distribution of buckets in Wards } \\
1,2,3,4,6,8,10,13,14\end{array}$ \\
\hline $\begin{array}{l}\text { Self-help group of } \\
\text { chpacho }\end{array}$ & NA & NA & $\begin{array}{l}\text { Cleanup program, plantation after } \\
\text { cleaning open disposal site in Ward } 9\end{array}$ \\
\hline $\begin{array}{l}\text { Child club of pobu and } \\
\text { Woman's group of pobu }\end{array}$ & NA & NA & Cleanup in Ward 10 \\
\hline $\begin{array}{l}\text { Nave chatrodaya } \\
\text { pustkalaya }\end{array}$ & NA & NA & Small scale training in SWM \\
\hline $\begin{array}{l}\text { Community-based } \\
\text { SWM Committee in } \\
\text { Wards } 13 \text { and } 14\end{array}$ & 2003 & 2 & $\begin{array}{l}\text { Collection of separated waste, } \\
\text { management of community } \\
\text { chambers in Wards } 13 \text { \& } 14 \text { (Since } \\
\text { March 2004, their activities have } \\
\text { been halted). }\end{array}$ \\
\hline $\begin{array}{l}\text { Community-based } \\
\text { SWM Committee in } \\
\text { Wards } 8 \\
\text { and } 10\end{array}$ & 2003 & 2 & $\begin{array}{l}\text { Collection of separated waste, } \\
\text { management of community chambers in } \\
\text { Wards } 8 \text { \& } 10 \text { (Since March 2004, their } \\
\text { activities have been halted). }\end{array}$ \\
\hline
\end{tabular}

Note:* According to MTM, there is a co-ordination with MTM at a program/activity level. NA means not available. Source: JICA Study Team, 2004 "Interview and Questionnaire Survey of Households, Establishments and NGOs/CBOs regarding Solid Waste Management in the Kathmandu Valley". 
Table 4 shows the summary of the NGOs and CBOs working in Madhyapur Thimi Municipality. Few NGOs and CBOs are working in Madhyapur Thimi Municipality. As the city is newly developed and less densely populated there are only nine private institutions working for the collection and management of waste generated within this municipality. These institutions are working for the better management of waste and improving the waste segregation habit of the households.

Table 5. Major NGOs/CBOs Working in the Field of SWM in KRM

\begin{tabular}{|l|l|l|l|}
\hline $\begin{array}{c}\text { Name of } \\
\text { NGOs/CBOs }\end{array}$ & \multicolumn{1}{|c|}{$\begin{array}{c}\text { Year of } \\
\text { foundation }\end{array}$} & Number of staff & \multicolumn{1}{c|}{ Working Areas } \\
\hline UNIQUE* & 1994 & 14 staff & $\begin{array}{l}\text { Door-to-door collection in Wards } \\
1,3,4,5,6,9,10,11,12,16 \text { and 17 (2,000 HHS) } \\
\text { compost, Training }\end{array}$ \\
\hline NEPCO* & 1998 & $\begin{array}{l}28 \text { paid staff } 7 \\
\text { volunteers }\end{array}$ & $\begin{array}{l}\text { Door-to-door collection (1,000 HHs) Partially } \\
\text { in Wards 1,2 and 3 }\end{array}$ \\
\hline $\begin{array}{l}\text { We Team / } \\
\text { Jai Kisahan }\end{array}$ & 2001 & $\begin{array}{l}5 \text { paid staff and } \\
760 \text { volunteers }\end{array}$ & Home compositing in Wards 3 and 12 (4 HHs) \\
\hline SOUP & 1992 & $\begin{array}{l}\text { 2 paid and 33 } \\
\text { volunteers }\end{array}$ & $\begin{array}{l}\text { Community development including } \\
\text { compositing in Ward 13 (15 HHs) }\end{array}$ \\
\hline
\end{tabular}

Source: JICA Study Team "Interview and Questionnaire Survey of Households, Establishments and NGOs/CBOs regarding Solid Waste Management in the Kathmandu Valley".

Note:* According to KRM, there is co-ordination with KRM at program/activity levels.

Table 5 shows the NGOs and CBOs working in Kiritipur Municipality. There are altogether four NGOs and CBOS working for the effective management of solid waste generated by the households and institutions. Since the Municipality is relatively new and has less physical infrastructure within it for the management of solid waste. Hence the NGOs and CBOs can play an effective role for the door to door collection and management of solid waste generated within it.

\section{CONCLUSION AND POLICY IMPLICATIONS}

This paper attempts to analyze the role of CBOs, NGOs and private institutions for the efficient management of solid waste in developing country cities. It attempts to reveal the experience of some of the developing country cities and analyze the role of CBOs, NGOs and Private institutions in Kathmandu Valley. Studies reveal that the best practice for the effective management of solid waste in developing country cities is considered as three Rs i.e. Reduce, Reuse and Recycling. Experience of developing country cities shows that community group NGOs and private institutions can play an effective role for the efficient management of solid waste. Involvement of these institutions not only helps to collect the municipal waste effectively but also reduces the costs to the municipality. 
Literatures show that in many developing country cities, community based institutions and NGOs are helping to improve collection of waste, composting of decomposable waste and reuse and recycling of other waste.

In Kathmandu Valley about 40 private institutions (including CBOS and NGOs) are working for making the city clean and managing solid waste within five municipalities and city oriented VDCs. These institutions are providing employment to about 5000 people directly and collecting about 60\% of the total waste generated within Kathmandu Valley from door-to-door. These institutions are contributing for the reduction of municipal cost for the collection of solid waste by about $40 \%$ of (Bhattarai 2010). Household segregation and compositing is considered as the best option for the cost effective management of municipal solid waste in Kathmandu since it reduces the volume of waste and minimize the cost (Bhattarai 2010). Local government alone cannot perform this task. This is possible only through the involvement of CBOs, NGOs and Private institutions.

\section{WORKS CITED}

Agunwamba, J.C. 1998 Solid Waste Management in Nigeria: Problems and Issues. Environmental Management 22(6):849-56.

Ahsan, T. and Safiul Azam Ahmad. 2000. Community Based Solid Waste Management Pilot Project in Khulna City: Problems and Prospects. In A.H.MD. Maqsood Sinha and Iftekhar Enayetullah (editors.) Community Based Solid Waste Management: The Asian Experience. Waste Concern, Dhaka, Bangladesh.

Bhattarai, R. C. 2010 The Benefit and Costs of Alternative Solid Waste Management Policies: A case of Kathmandu Metropolitan City. Nepalese Economic Review (NER), Volume 2, Number 3 Bishleshan Pvt. Ltd., New Plaza Kathmandu, Nepal.

Bharati, C. 1998. Public Waste Private Enterprise: An enquiry into the issue of integrating rag pickers into formal Solid Waste Management Systems. The Heinrich Boell Stiftung, Berlin.

DFID. (1999. Effective Solid Waste Management with the Participation of Waste Producers. Department for International Development (DFID), Delhi.

Enayetullah, A.H. and M. D. Maqsood Sinha. 2000. Community Based Decentralized Compositing: Experience of Waste Concern in Dhaka. In A.H. MD. Maqsood Sinha and Iftekhar Enayetullah (editors.) Community Based Solid Waste Management: The Asian Experience. Waste Concern, Dhaka, Bangladesh.

Christine, F. 1996. Household-Level and Community Actions for Solid Waste Management and Recycling in Asian Cities: Recent Research and Projects. Recycling in Asia, Partnership for Solid Waste Management. United Nations Centre for Regional Development Nagoya, Japan. 
Furedy and M.S. Shivakumar. 1990. Reforming Solid Waste Management Perspectives of Concerned Citizens. Paper presented at the International Seminar on Solid Waste Management and Resource Mobilization, October 28-Nov. 4, 1990 Kathmandu, Nepal.

JICA, 2005. The study on the Solid Waste Management for the Kathmandu Valley, Nippon Koei Co. Ltd., Yachiyo Engineering Co. Ltd.

Lal, M. 2000. Profits from Waste: NGO Led Initiative for Solid Waste Management in Lucknow. In A.H. Md. Maqsood Sinha and Iftekhar Enayetullah. (editors.) Community Based Solid Waste Management: The Asian Experience, Waste Concern, Dhaka, Bangladesh.

Mwanthi, M.A., L.O. Nyobola, and E. Tenambergen. 1997. Solid Waste Management in Nairobi city: Knowledge and Attitudes. Journal of Environmental Health. 60(5):23-30.

Nirmal, M.B. 2000. Community Based Solid Waste Management: Experience of Exnora. In A.H.Md. Maqsood Sinha and Iftekhar Enayetullah (editors.) Community Based Solid Waste Management: The Asian Experience. Waste Concern, Dhaka, Bangladesh.

Ogu, V.I. 2000. Private Sector Participation and Municipal Waste Management in Berlin City Nigeria. Environmental and Urbanization. 12(2):103-17.

Ojeda, Benitez, Sara Carolina Armijode Vega and Ma Clizabeth Ranirez Barreto, 2000. The Potential for Recycling Household Waste. A Case Study from Mexicali Mexico, Environment and Urbanization 12(2):103-17.

Qureshi, A.P. 2000. Waste Busters: An Experience of Pakistan in A.H. MD. Maqsood Sinha and Ifetkhar Enayetullah (editors) Community Based Solid Waste Management: The Asian Experience. Waste Concern, Dhaka, Bangladesh.

Reddy, S. and S. Galab. 1998. An Integrated Economic and Environmental Assessment of Solid Waste System in India: The Case of Hyderabad. A Research Report Prepared for Centre for Economic and Social Studies, Andra Pradesh, India.

Sarageldin, Michael A. Cohen, and K.C. Sivaramakrishnan. 1995. The Human Face of the Urban Environment. Environmentally Sustainable Proceedings, Washington D.C. World Bank.

Sinha, A.H. MD. Maqsood, and Iftekhar Enayetullah (editors). 2000. Community Based Solid Waste Management: The Asian Experience. Waste Concern, Dhaka, Bangladesh. 
Sisodia R.P. 2000. Innovations in Community Based Solid Waste Management Initiatives: Hyderabad Experiment. in A.H. MD. Maqsood Sinha and Iftekhar Enayetullah. (editors). Community Based Solid Waste Management: The Asian Experience. Waste Concern, Dhaka, Bangladesh.

Srinivas, V. 1996. The Role of Informal Sector in Urban Waste Management Some Issues. Enaology. 11(7):15-20.

SWMRMC 2009. Report on Existing Situation of Solid Waste Management in Kathmandu Valley, Solid Waste Management and Resource Mobilization Center, Kathmandu.

UNDP-World Bank. 1999. Community-Based Action Planning for Effective Solid Waste Management. Water and Sanitation Program in South Asia. United Nations Development Program and The World Bank.

World Bank. 1999. What a Waste: Solid Waste Management in Asia. Urban Development Division, The World Bank.

Yhdego. 1995. Urban Solid Waste Management in Tanzania: Issues, Concepts and Challenges. Resources, Conservation and Recycling. 14:1-10. 